annum, with up to $£ 50$ per annum for research expenses. Further information can be obtained from the Secretary, Medical Research Council, 38 Old Queen Street, Westminster, S.W.1.

\section{Earthquakes in Japan and Greece}

AN earthquake, reported as the strongest for five years, shook several parts of the island of Kyushu at 12.22 p.m. local time on March 20 (3.22 G.M.T.). The shock was felt in Fukuoka but appears to have been strongest in Miyasaki where property and power lines were damaged and twenty people injured. The nearest active epicentre to this region appears to be $31 \cdot 8^{\circ} \mathrm{N}$., $131 \cdot 8^{\circ} \mathrm{E}$. where shocks occurred on 1929 $5 \mathrm{~m}$. $21 \mathrm{~d}$., and $6 \mathrm{~m}$. $11 \mathrm{~d}$. There are three lines of weakness near the island of Kyushu according to Imamura: two pass through Nagasaki and run roughly east-north-east and south-south-east whilst the other is just off, and approximately parallel to, the south-east coast.

AN earthquake shock of considerable intensity was felt on March 27 in Athens and other Greek towns though no great damage is reported. The epicentre of the shock was probably near Chalcis though very little information is at present available. It will be remembered that the centre of the disturbances on July 20,1938 , was near $38 \cdot 35^{\circ}$ N., $23 \cdot 8^{\circ}$ E., near Scala Oropos.

\section{Royal Geographical Society: Awards}

His MAJESTy THE KING has approved the award of the Royal Medals of the Royal Geographical Society as follows: The Founder's Medal to Mr. Arthur Mortimer Champion, for his surveys of the Turkana Province and the volcanoes south of Lake Rudolf; the Patron's Medal to Prof. Hans Ahlmann of Stockholm, for his exploration and glaciological studies in the Arctic. The Council has awarded the Murchison Grant to Mr. Robert Bentham, for his mapping and geological investigations in Ellesmere Land ; the Back Grant to Liout.-Commander R. E. D. Ryder, for his captaincy of the Penola and his marine surveys on the British Graham Land Expedition; the Cuthbert Peek Grant to Mr. W. Vaughan Lewis, for his physiographical studies in Great Britain and Iceland; the Gill Memorial to Mr. J. V. Harrison, for many years' exploration in Central and South America and Southern Iran.

\section{Announcements}

Colonel J. A. Manifold has been appointed director of hygiene at the War Office in succession to Major-General H. H. A. Emerson, who will retire shortly.

The Herbert Jackson Prize for 1938 of the L.M.S. Railway Co. has been awarded to Mr. J. N. Bradley, an assistant metallurgist in the Company's Research Laboratory at Derby, for his paper entitled "The Separation of Mixed Gunmetal and White Metal Borings". A Jackson Medal has also been awarded to Mr. C. W. Newberry, research assistant in the engineering section of the same Laboratory, for a paper entitled "An Investigation into the Occurrence and Causes of Locomotive Tyre Failures". The Herbert Jackson Prize is awarded annually by the L.M.S. in memory of the late Sir Herbert Jackson (an original member of the L.M.S. Advisory Committee on Scientific Research), to a member of the Company's research staff for the best written account of an investigation carried out in the Companies' Laboratories during the year.

AT the annual general meeting of the Ray Society held on March 23, the following officers were reelected : President, Sir Sidney F. Harmer ; Treasurer, Prof. F. E. Weiss; Secretary, Dr. W. T. Calman. Dr. John Ramsbottom was elected a vice-president, and Mr. E. R. Martin, Mr. D. M. Reid, and Col. R. B. Seymour Sewell were elected new members of Council. It was announced that a "Bibliography of the larvæ of Decapod Crustacea" by Dr. R. Gurney, and the first of two volumes on "The Comity of Spiders" by Dr. W. S. Bristowe are in the press and will be published shortly. The first volume of a work on "British Water Beetles" by Prof. F. Balfour-Browne is nearly completed and will form the issue to subscribers for 1939 .

Tне University of Pavia has arranged a celebration in honour of the eighteenth-century physiologist, biologist and vulcanologist, Spallanzani (1729-1799), which is to be held in Pavia on April 11-14. A monument to Spallanzani is to be unveiled and a programme of scientific addresses, mainly on modern genetical problems and the physiology of reproduction, is being prepared by delegates invited from various countries, including Prof. R. Ruggles Gates, Prof. F. A. E. Crew and Dr. C. F. Pantin from Great Britain. Meetings of the societies for experimental biology, botany, geology and veterinary medicine are also being held at the University, and on April 15 a visit will be paid to the Spallanzani Museum at Reggio Emilia.

IN 1937 the birth-rate in the U.S.S.R. was 18-19 per cent higher than in 1936 and the increase in population was a little more than 2 per cent. During the first ten months of 1938 there were 100,000 more marriages in the Soviet Union than in the corresponding period of 1937 .

Prof. V. A. Fock, of the University of Leningrad, writes that the transcription of his name in the article on the U.S.S.R. Academy of Sciences in NATURE of February 25, p. 343, namely, Fok, is incorrect and should be as here indicated.

ERratum. In the list of "Forthcoming Books of Science" in NATURE of March 11, p. 428, the volume by Prof. E. J. Conway to be published by Messrs. Crosby Lockwood and Son, Ltd., should be entitled "Microdiffusion Analysis and Volumetric Error". 